PF 2019 (LXXIV): 13-30

\author{
JADWIGA WANIAKOWA \\ Pracownia Etymologii i Geolingwistyki \\ Instytut Języka Polskiego Polskiej Akademii Nauk \\ al. Mickiewicza 31 \\ 31-120 Kraków \\ tel. +48 12 632-56-92 (centrala)
}

\title{
JUBILEUSZ PROFESORA JANUSZA SIATKOWSKIEGO
}

Profesor Janusz Siatkowski, doktor honoris causa Uniwersytetu Karola w Pradze, wybitny slawista o międzynarodowej renomie, znawca dialektologii słowiańskiej, historii języków słowiańskich, specjalista w zakresie międzysłowiańskich i słowiańsko-niemieckich kontaktów językowych, a także leksykograf, 5 marca 2019 roku obchodził piękny jubileusz 90-lecia. Czuję się niezwykle zaszczycona, że dane mi napisać o nim $\mathrm{z}$ tak wspaniałej okazji. Do tej pory już dwie osoby nakreśliły sylwetkę Profesora. W roku 1999 uczyniła to prof. Hanna PopowskaTaborska (1999: 9-12) z okazji 70. urodzin Uczonego, potem, w roku 2014, pisał o nim prof. Stanisław Dubisz (2014: 293-299), upamiętniając 85. urodziny Jubilata. Wtedy też została wydana w osobnej publikacji bibliografia Profesora (Dorobek naukowy Profesora Janusza Siatkowskiego w opracowaniu Ignacego Dolińskiego, Zdzisława Kłosa i Doroty Krystyny Rembiszewskiej), obejmująca lata 1951-2013. Została bardzo pomysłowo opracowana, bowiem zawiera kolorowe zdjęcia okładek wydawnictw zwartych, których autorem bądź współautorem jest Profesor Siatkowski. Na uwagę też zasługuje jej osobliwa okładka, której pierwsza strona jest zwykła, czyli poważna i naukowa, ostatnia zaś, zarówno w treści, jak i w formie, odnosi się do charakteru Jubilata, a więc jest pełna humoru i zawadiacko młodzieńcza.

O Profesorze Januszu Siatkowskim, mimo że jest wybitnym uczonym i Dostojnym Jubilatem, nie można pisać tylko poważnie, bo wtedy w żaden sposób nie ujęłoby się całości jego sylwetki. Dostrzegła to już prof. Popowska-Taborska, dzieląc swój tekst na dwie części: pierwszą - oficjalną (encyklopedyczną) i drugą - mniej oficjalną (widzianą oczami przyjaciół). Również prof. Dubisz w końcowej części swego tekstu o Profesorze Siatkowskim zamieścił osobiste refleksje o Jubilacie. 

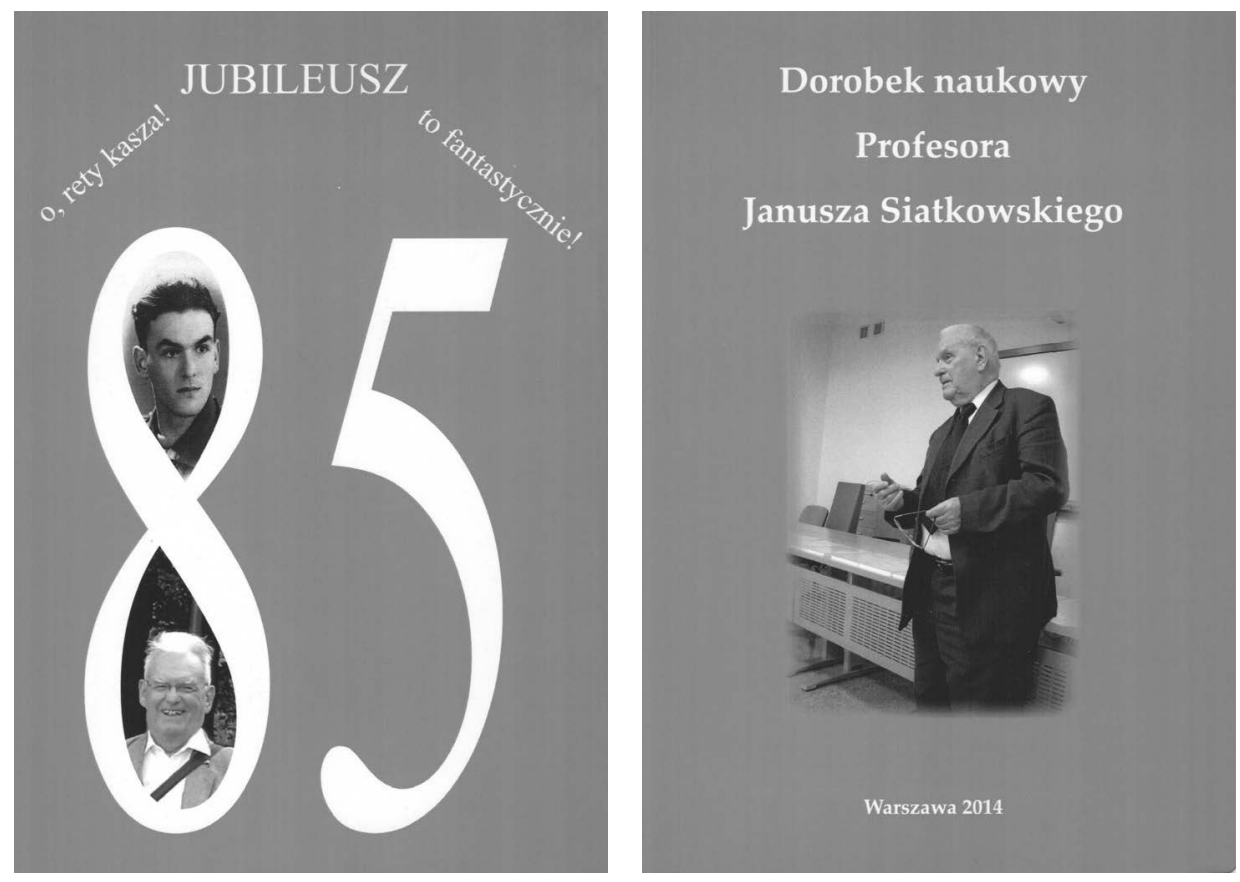

W niniejszym szkicu chciałabym odwrócić trochę ten porządek. Mianowicie najpierw chcę powiedzieć kilka słów o Profesorze Siatkowskim jako ujmującym człowieku z dużym poczuciem humoru i wspaniałym gawędziarzu, ponieważ wydaje mi się to szczególnie ważne w opisie jego sylwetki, następnie pragnę przedstawić w skrócie jego drogę naukową, wymienić liczne funkcje naukowe i organizacyjne, potem pragnę krótko scharakteryzować jego bogaty dorobek naukowy (bardziej szczegółowe omówienie ogromnych dokonań naukowych zajęłoby bowiem całą książkę!), a na koniec chcę wymienić polskie i zagraniczne wyróżnienia w uznaniu wielkich zasług naukowych Profesora.

Jaki zatem jest Profesor Janusz Siatkowski „pozanaukowo”? Z pewnością niezwykle słowny. Poznałam go w roku 1999 na konferencji w Mogilanach pod Krakowem, gdzie wygłaszał referat o nazwach pomidora w językach Europy. Ponieważ sama kiedyś pisałam o nazwach pomidora w językach słowiańskich, podeszłam i mu to powiedziałam. "Jeśli Pani chce, żebym się zapoznał z Pani tekstem, proszę mi przesłać jego dane bibliograficzne". Potem jego referat został opublikowany (por. Siatkowski 2002a: 201-204). W tekście tym jest odwołanie do mego artykuliku (por. Waniakowa 1999: 57-64). Nie zapomniał!

W dwa lata później znów los mnie z nim zetknął. Zadzwonił i niespodziewanie zaczął mnie namawiać, bym zajęła się Atlasem Linguarum Europae (ALE). Długo przekonywał, tłumaczył, że się do tego nadaję. Tylko jego wielkiej sile 
przekonywania należy przypisać to, że przy tym atlasie pracuję. Drugi raz jego siła perswazji objawiła się przy zatrudnieniu mnie przy Ogólnosłowiańskim atlasie językowym (OLA) w roku 2004. Pamiętam pierwsze wyjazdy na spotkania atlasowe. Wtedy sobie po raz pierwszy w pełni uświadomiłam, jakim autorytetem jest Profesor Janusz Siatkowski. Zobaczyłam, jak rozległą ma wiedzę, jaki ogromny respekt budzą jego merytoryczne uwagi, z jak wielkim szacunkiem odnoszą się do niego zagraniczni uczeni. Dużo się od niego uczyłam, wyjaśniał mi wiele kwestii historycznojęzykowych i geolingwistyczno-dialektologicznych. Ważne, że czynił to w przyjazny i miły sposób, bez żadnego mentorstwa czy napuszoności, wręcz przeciwnie, $\mathrm{z}$ dużym poczuciem humoru. Jest to jedna $\mathrm{z}$ cech podstawowych Janusza Siatkowskiego, powiedziałabym, cecha dystynktywna. Pamiętam, jak kiedyś przy okazji spotkania atlasowego, zwiedzaliśmy w wielkim upale Dubrownik. Gdy wspominaliśmy potem ten wielogodzinny spacer w palącym słońcu, rzekł: „tak, tak, mało wtedy nie umarłem!". Powiedział to oczywiście po swojemu, najpierw porozumiewawczo błysnął okiem, a potem mrugnął...

Inną dominującą cechą charakteru Profesora Siatkowskiego jest jego rycerskość. Tak właśnie, rycerskość. Mam tu na myśli nie tylko nienaganne formy towarzyskie, ale przede wszystkim nawyk obrony niesłusznie atakowanych naukowo. Sama aż dwukrotnie doświadczyłam takiej sytuacji i jestem do tej pory pełna wdzięczności za jego zachowanie, zwłaszcza że okazywał się jedynym obrońcą i miał odwagę czynić to publicznie.

Profesor lubi spacerować, mówi „hop!”, ochoczo wstaje i dziarsko rusza naprzód poznawać świat. Cechuje go prawdziwie młodzieńcza ciekawość świata i chęć zobaczenia czegoś nowego. Lubi wspominać wycieczki górskie, w których uczestniczył i opowiadać, jak wybierał się w góry także samotnie, przy tym nie chodzi tylko o góry w Polsce, ale też za granicą.

Skłonność do turystyki rozwinęła $w$ nim doskonałą orientację w rozkładach jazdy pociągów, w czym zawsze pomagała mu świetna pamięć. Toteż w podróży można mu w pełni zaufać i być pewnym, że nie wsiądzie się do niewłaściwego pociągu. Z Januszem Siatkowskim można też bez obawy się znaleźć w zupełnie obcym miejscu. Ma znakomitą orientację w terenie. Bezbłędnie wszędzie trafia, nie pozwala się nikomu zgubić, co mnie zawsze wprawia w podziw. Niektóre miejsca zna jak własną kieszeń (wedle jego własnych słów), na przykład Paryż, gdzie często bywa, odwiedzając córkę Kingę, zatrudnioną na Sorbonie.

Jest bardzo dumny ze swoich dzieci i wnuków, potrafi o nich długo i z przejęciem opowiadać. Gdy dzieci były małe, przykładnie się nimi zajmował i jeździł z nimi na wakacje, potem równie chętnie jeździł na wakacje $\mathrm{z}$ wnukami. Jest wyjątkowo rodzinny, bardzo dobrze gotuje i poświęca sporo czasu domowi. Nie jestem gołosłowna, kilka razy byłam u Państwa Siatkowskich w domu i miałam okazję jeść doskonałe obiady. Tę cechę Jubilata ceni też jego 
Żona, prof. Ewa Siatkowska, z którą od początku poczułyśmy bliskość jako zodiakalne raki.

Gdy jestem w mieszkaniu Państwa Siatkowskich, za każdym razem ogromnie wrażenie robi na mnie ich olbrzymia biblioteka. Jest tam wszystko - począwszy od słowników gwarowych języków słowiańskich, poprzez słowniki historycznojęzykowe, słowniki etymologiczne słowiańskie i europejskie, szczegółowe opracowania konkretnych zagadnień językoznawczych, a skończywszy na atlasach językowych. Jest to po prostu kopalnia wiedzy na półkach. Biblioteka jest oczywiście cały czas powiększana o najnowsze pozycje. Gdy się ogarnie wzrokiem tę niezliczoną liczbę woluminów, nie ma się wątpliwości, że Profesor Janusz Siatkowski to przede wszystkim światowej klasy uczony.

Prof. dr hab. Janusz Siatkowski, urodzony 5 marca 1929 roku w Warszawie, jest wybitnym językoznawcą, polonistą, bohemistą i slawistą. Studiował filologię polską na Uniwersytecie Warszawskim w latach 1948-1952. Przy tym w roku akademickim 1950/1951 przebywał na Uniwersytecie Karola w Pradze, gdzie uczęszczał na zajęcia z bohemistyki. Na początku roku 1953 uzyskał magisterium za pracę dialektologiczną pt. Stownictwo warmińsko-mazurskie z zakresu budownictwa, napisaną pod kierunkiem prof. Witolda Doroszewskiego (Dubisz 2014: 293). Warto wspomnieć, że Janusz Siatkowski zaczął pracować zawodowo już w czasie studiów, mianowicie w latach 1950-1952 był zatrudniony w Zakładzie Języka Polskiego Uniwersytetu Warszawskiego (najpierw jako zastępca asystenta, potem jako asystent). To pozwoliło mu brać udział w pracach terenowych Zespołu Dialektologicznego przy Zakładzie, prowadzonych w Ostródzkiem, na Warmii i Mazurach, a kierowanych przez prof. Witolda Doroszewskiego i prof. Halinę Koneczną. Podczas tych wyjazdów gromadził materiały do wspomnianej wyżej pracy magisterskiej, wydanej kilka lat później w formie książki (por. Siatkowski 1958a). Praca ta odbiła się szerokim echem w środowisku językoznawczym. Była wielokrotnie recenzowana w kraju i za granicą. Należy dodać, że jako pracownik Zakładu prowadził też zajęcia dla studentów (m.in. z gramatyki historycznej języka polskiego i gramatyki języka staro-cerkiewno-słowiańskiego), zdobywając w ten sposób doświadczenie dydaktyczne (Dubisz 2014: 294, 297).

Po ukończeniu studiów był zatrudniony przez kilka lat (1953-1956) w Katedrze Filologii Słowiańskiej na Uniwersytecie Warszawskim, z początku jako aspirant, potem starszy asystent. W roku 1954 zaangażował się w prace terenowe nad Atlasem kaszubszczyzny i dialektów sąsiednich, prowadzone pod kierunkiem prof. Zdzisława Stiebera. Prof. Hanna Popowska-Taborska (1999: 10) wspomina, że warszawski kolega zaimponował jej wówczas „swoją rozległą wiedzą dialektologiczną i gruntowną orientacją we wszystkich realiach wsi”. Podkreśla także, że $\mathrm{z}$ ogromnym entuzjazmem angażował się $\mathrm{w}$ badania terenowe i wszelkie naukowe prace zespołowe. W tym czasie też, nie z własnej woli, a drogą odgórnej decyzji 
władz - jak pisze prof. Popowska-Taborska (1999: 11) - Janusz Siatkowski zmienił swego naukowego mistrza. Miał odtąd pracować (od sierpnia 1956 roku) w Zakładzie Słowianoznawstwa Polskiej Akademii Nauk, kierowanym przez prof. Zdzisława Stiebera, który stał się promotorem jego rozprawy doktorskiej. On to zachęcił nowego ucznia - mając na uwadze jego naukowy pobyt w Pradze - do badań nad dialektem czeskim w okolicach Kudowy. Praca doktorska Janusza Siatkowskiego dotyczyła zatem dialektologii czeskiej (por. Siatkowski 1962a, 1962b). Jej obrona miała miejsce w maju 1960 roku na Uniwersytecie Warszawskim, a Autor dysertacji uzyskał stopień doktora nauk humanistycznych w zakresie filologii słowiańskiej (por. Dubisz 2014: 293). Jak zauważa prof. Popowska-Taborska (1999: 11), „polski świat językoznawczy zyskał [...] pilnego i wieloletniego badacza bohemizmów". Wydane na podstawie doktoratu dwie książki znalazły szeroki oddźwięk nie tylko w Polsce, ale i w Czechach, gdzie uzyskały wiele pochlebnych recenzji.

Rozprawa habilitacyjna Janusza Siatkowskiego dotyczyła także tematyki bohemistycznej, tym razem jednak było to ujęcie przede wszystkim diachroniczne. Autor zajął się mianowicie czeskimi zapożyczeniami fonetycznymi w języku polskim (por. Siatkowski 1965a). Na podstawie tej pracy i pozostałego dorobku uzyskał w roku 1965 habilitację.

Kolejne liczne publikacje przyczyniły się do otrzymania przez Janusza Siatkowskiego w roku 1972 tytułu profesora nadzwyczajnego, a w roku 1979 profesora zwyczajnego. W Zakładzie (potem Instytucie) Słowianoznawstwa PAN (dziś Instytut Slawistyki PAN) Janusz Siatkowski przeszedł przez kilka stanowisk: od adiunkta (1956-1968), potem docenta (1968-1972) aż do profesora (1972-1982). Pełnił też tam kolejno wiele odpowiedzialnych funkcji administracyjnych: w latach 1972-1973 był zastępcą kierownika Zakładu, w latach 19741977 jego kierownikiem, a następnie, w latach 1977-1982, dyrektorem Instytutu Słowianoznawstwa ${ }^{1}$.

W roku 1982 na powrót stał się pracownikiem Uniwersytetu Warszawskiego. Został zatrudniony w Instytucie Filologii Słowiańskiej (dziś Instytut Slawistyki Zachodniej i Południowej). W latach 1985-1990 był kierownikiem Zakładu Filologii Bułgarskiej w tym Instytucie, potem, w latach 1992-1997, kierownikiem Zakładu Języków Słowiańskich, będąc także prawie równocześnie, bo w latach 1993-1999, dyrektorem całego Instytutu. Wcześniej, w latach 1986-1990, pełnił również funkcję prodziekana Wydziału Polonistyki (por. Popowska-Taborska 1999: 9; Dubisz 2014: 297). Na Uniwersytecie Warszawskim był zatrudniony aż do emerytury.

1 W roku 1977 Zakład Słowianoznawstwa PAN został przemianowany na Instytut Słowianoznawstwa PAN. 
Bibliografia publikacji Profesora Janusza Siatkowskiego od roku 1951 do tej pory (styczeń 2019) obejmuje (nie licząc prac redaktorskich) prawie 400 pozycji². Pierwszą jego publikacją, która ukazała się drukiem, jeszcze za czasów studenckich, był tekst gwarowy pt. Z gwary warmińsko-mazurskiej. Bajka o Panu Bogu, diable $i$ krowie w „Poradniku Językowym” z roku 1951. Potem przyszła kolej na następne artykuły, recenzje i książki. Profesor ma w swoim dorobku naukowym kilkanaście książek ( $w$ tym jeden słownik we współautorstwie i trzy współautorskie monografie). Są to, prócz pozycji wymieniowych wyżej, następujące dzieła: Bohemizmy fonetyczne w języku polskim, cz. II: 4. Formy beznosówkowe; 5. Formy nieprzegłoszone (1970), Slawizmy w utworach ślaskich Horsta Bienka (1995), Slawismen in den schlesischen Romanen von Horst Bieniek (2000, wersja niemiecka), Czesko-polskie kontakty językowe (1996), Studia nad wplywami obcymi w Ogólnosłowiańskim atlasie językowym (2004), Słowiańskie nazwy wykonawców zawodów w historii i dialektach (2005), Obce nazwy geograficzne w języku czeskim i polskim (2006), Słowiańskie nazwy części ciała w historii i dialektach (2012) i Studia nad słowiańsko-niemieckimi kontaktami językowymi (2015). Prócz tego wydał we współautorstwie z prof. Mieczysławem Basajem trzykrotnie potem wznawiany Słownik czesko-polski (Česko-polskýslovník) (1991, wyd. 2 poprawione 2002, wyd. 3 - 2007, wyd. 4 - 2010) oraz trzy współautorskie monografie: Bohemizmy w języku polskim. Słownik ${ }^{3}$ (2006, z prof. Mieczysławem Basajem), Różnojęzyczne słownictwo gwarowe Podlasia, Suwalszczyzny i pótnocno-wschodniego Mazowsza (2014, z prof. Ireną Maryniakową i prof. Dorotą Krystyną Rembiszewską) oraz ostatnio: Pogranicze polsko-wschodniosłowiańskie. Studia wyrazowe (2018, z prof. Dorotą Krystyną Rembiszewską).

Jubilat ma na koncie także ważne współautorskie prace edytorskie. Jest to Wybór tekstów staroczeskich, opublikowany w roku 1967 wspólnie z prof. Ewą Siatkowską (drugie wydanie w roku 1988) oraz Gesta Romanorum linguae polonicae (1543) cum fontibus latinis et bohemicis adiuvante R. Olesch nunc iterum edidit J. Siatkowski (wydane w Kolonii i Wiedniu w roku 1986).

Niezwykle szeroka tematyka monografii odzwierciedla bogate spectrum zainteresowań badawczych Jubilata. Profesor Janusz Siatkowski jest wybitnym znawcą historii polszczyzny i jej dialektów, a także kaszubszczyzny oraz specjalistą w zakresie historii języka czeskiego i jego gwar. Interesuje go żywo język bułgarski i słowacki, ponadto języki łużyckie i wschodniosłowiańskie. Sporo uwagi poświęca językowi niemieckiemu, a zwłaszcza wzajemnym językowym kontaktom

2 Por. dane bibliograficzne ze strony Instytutu Slawistyki PAN: http://ispan.waw.pl/default/ pl/uczeni-z-kregu-is-pan/1108-prof-dr-hab-janusz-siatkowski [dostęp: 12.01.2019].

3 Pracę tę, mimo skromnego podtytułu, zaliczam do monografii, bowiem jest to $\mathrm{w}$ istocie dogłębne i wielostronne opracowanie wyrazów uważanych za bohemizmy w języku polskim. 
polsko-niemieckim i słowiańsko-niemieckim (przede wszystkim w zakresie gwar). Zajmuje się wpływem języka niemieckiego na polski i inne języki słowiańskie, ale także oddziaływaniem języka polskiego i języków słowiańskich na niemiecki. Kontakty językowe stanowią dla Jubilata niezwykle interesujące pole badawcze. Zajmuje się szczegółowo wzajemnymi interferencjami języków słowiańskich, jak i zapożyczeniami obcymi w Słowiańszczyźnie, przede wszystkim w ujęciu diachronicznym. Dorobek naukowy Profesora Janusza Siatkowskiego obejmuje zatem całą Słowiańszczyznę i jej kontakty językowe z językami pozasłowiańskimi.

W te wszechstronne zainteresowania naukowe Jubilata wpisują się też jego inne publikacje, mianowicie artykuły i recenzje. Dość trudno podzielić je na poszczególne nurty, bo się one w twórczości Profesora Janusza Siatkowskiego splatają i często jeden artykuł odnosi się do kilku problemów (na przykład publikacje dotyczące historii języka polskiego traktują jednocześnie o wpływach czeskich bądź staro-cerkiewno-słowiańskich na polszczyznę, a teksty poświęcone wpływom czeskim na polszczyznę nie tylko konfrontują oba języki, ale też odwołują się do historii i dialektów ich obu). Dzieje się tak, ponieważ Autor w swoich pracach zawsze dokonuje dogłębnej i wielostronnej analizy omawianych zjawisk, co świadczy nie tylko o jego niezwykłej erudycji, ale też o nadzwyczajnej wnikliwości badawczej.

Część artykułów weszła do wyżej wymienionych monografii, na przykład książka Czesko-polskie kontakty językowe (1996) zawiera wcześniej opublikowane artykuły o tej problematyce, a praca Słowiańskie nazwy wykonawców zawodów $w$ historii i dialektach (2005) składa się z uzupełnionych wersji wcześniejszych tekstów poświęconych poszczególnym nazwom z tego zakresu w językach słowiańskich.

Jakkolwiek poruszana w pracach Profesora Janusza Siatkowskiego tematyka jest niezwykle szeroka, a szczegółowe problemy wzajemnie się ze sobą wiążą (por. wyżej), to można jednak wyróżnić w jego olbrzymiej twórczości naukowej szereg działów, do których należą się kolejne publikacje.

I tak do dialektologii polskiej zaliczyć można dwa wczesne teksty dotyczące gwar warmińsko-mazurskich (por. Siatkowski 1960, 1964) oraz późniejszą publikację o interferencjach językowych na tymże obszarze (por. Siatkowski 1983a) ${ }^{4}$. Do tego trzeba dodać artykuł o współczesnej sytuacji językowej w okolicach Kudowy (Siatkowski 1990a) ${ }^{5}$ i pracę na temat etymologii burszówki (Siatkowski 1996a). Warto też tutaj nadmienić, że Jubilat jest współautorem Kwestionariusza do badań słownictwa ludowego (1958) pod red. W. Doroszewskiego.

4 Tekst ten należy zarazem do problematyki kontaktów polsko-niemieckich.

5 Publikacja traktuje oczywiście o gwarowych kontaktach polsko-czeskich. 
Przedmiotem zainteresowania Profesora jest także historia języka polskiego w szerokim ujęciu porównawczym ze szczególnym uwzględnieniem wpływów innych języków na polszczyznę. Tu plasują się prace na temat wydań Katechizmu Mikołaja Reja (Siatkowski 1967a), tekst o rozwoju polskiej ortografii (por. Siatkowski 1973), liczne artykuły na temat wpływów staro-cerkiewno-słowiańskich na polszczyznę (por. np. Siatkowski 1982) i wpływów czeskich (np. Siatkowski 1990b) oraz prace o języku Historii rzymskich (np. Siatkowski 1985) ${ }^{6}$.

Kolejnym obszarem badawczym Jubilata jest kaszubszczyzna. Tu należą szcze-

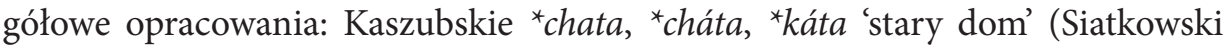
1962c) oraz: Kasz. merlica - ps. ${ }^{*}$ mbrlica (Siatkowski 1997). Nie można pominąć też prac o kaszubskim ścieśnionym $a$ (Siatkowski 1962d, 1965b), jak również recenzji słownika zapożyczeń niemieckich w kaszubszczyźnie Friedhelma Hinzego (por. Siatkowski 1965c), która odnosi się przede wszystkim do problematyki kontaktów językowych.

Profesor Janusz Siatkowski od początku swojej kariery naukowej interesuje się językiem czeskim, jego historią, gwarami oraz wzajemnymi wpływami polsko-czeskimi w ujęciu diachronicznym. Tym zagadnieniom poświęcił szereg prac, począwszy od publikacji na temat czechizmów w języku Jana z Koszyczek (Siatkowski 1959), poprzez wspomniane już wyżej niezwykle liczne artykuły o wpływach czeskich na polszczyznę, kontaktach językowych polsko-czeskich (por. Siatkowski 1978, 1984a, 1994a) i prace zarówno na temat gwar czeskich w Polsce (uwieńczone niedawnym artykułem o obecnej sytuacji językowej w okolicach Kudowy, por. Siatkowski 2017a), jak i dialektów w samych Czechach (por. np. Siatkowski 1976) po cykl szczegółowych studiów wyrazowych, dotyczących leksemów uważanych za bohemizmy (opracowywanych we współautorstwie z prof. Mieczysławem Basajem i publikowanych w „Rozprawach Komisji Językowej Łódzkiego Towarzystwa Naukowego" w latach 1964-1980), które potem wydano razem we wzmiankowanym już wyżej słowniku w roku 2006. Nie sposób nie wspomnieć o dwóch niezwykle ważnych pozycjach $\mathrm{z}$ tego zakresu, mianowicie o niedawnej pracy Czesko-polskie pogranicze językowe w świetle ankiet Georga Wenkera (red. D.K. Rembiszewska, Warszawa 2017, s. 89 + mapa) oraz o tłumaczeniu studium Władysława Nehringa, Wpływ języka i literatury staroczeskiej na język i literaturę staropolską (przełożył Janusz Siatkowski, do druku przygotował, posłowiem i indeksami opatrzył Mieczysław Balowski, Poznań 2017, s. 188). Jubilat zajmuje się także obcymi nazwami własnymi w języku czeskim w ujęciu porównawczym z odpowiednikami polskimi. Poświęcił temu zagadnieniu szereg prac (por. np. Siatkowski 1991a) ze wspomnianą wyżej książką włącznie (2006). Jako wybitny specjalista regularnie recenzuje najważniejsze prace językoznawcze

6 Por. w tym kontekście wspomniane wyżej wydanie Gesta Romanorum [...]. 
powstające w Czechach (w tym Czeski atlas językowy) i przybliża polskiemu czytelnikowi współczesny stan językoznawstwa czeskiego (por. np. Siatkowski 2000a).

Zagadnienia językowe czeszczyzny stanowią jeden z głównych nurtów badawczych Jubilata, ale poświęca on swoją uwagę także innym językom słowiańskim. Na przykład z zakresu języka słowackiego opublikował wraz z prof. Ewą Siatkowską artykuł o słowackich nazwach miejscowych (por. Siatkowska E., Siatkowski J., 1990). Recenzował też słownik gwar słowackich. Zajął się również łużyckim przyrostkiem - awa w niemieckich gwarach brandenburskich (por. np. Siatkowski 1999a $)^{7}$. Poza tym recenzował prace z zakresu językoznawstwa łużyckiego. Sporo uwagi w swojej pracy naukowej poświęca Jubilat językowi bułgarskiemu. Zajmuje się przede wszystkim porównawczym słowotwórstwem polsko-bułgarskim (por. Siatkowski 1984b; Bałtowa, Siatkowski 1993), w takimż ujęciu nazwami miejscowymi (por. Siatkowski 1987a) oraz pożyczkami tureckimi w zakresie bułgarskiej frazeologii (np. Siatkowski 1988). Jego zainteresowania obejmują też język staro-cerkiewno-słowiański (por. Siatkowski 1987b) i rosyjski (zob. Siatkowski 2011). Dużo prac Profesora Janusza Siatkowskiego dotyczy zagadnień ogólnosłowiańskich, z biegiem czasu tego rodzaju publikacji jest coraz więcej (por. np. Siatkowski 1986, 1991b, 2001), też we współautorstwie (por. Rembiszewska, Siatkowski 2015, 2016, 2017).

Wiele uwagi poświęca Profesor Janusz Siatkowski językowi niemieckiemu i jego dialektom, historycznym związkom języka niemieckiego z polskim, a przede wszystkim kontaktom gwarowym polsko-niemieckim. Zagadnienia te ujmuje bardzo szeroko, bowiem zajmuje się również kontaktami słowiańsko-niemieckimi. Jubilat zaczął zgłębiać tę problematykę, publikując doskonałe studium na temat wpływu poszczególnych dialektów niemieckich na język polski (por. Siatkowski 1967b). Potem badał między innymi efekty kontaktów polsko-niemieckich w gwarach niemieckich (por. np. Siatkowski 1983b), wpływ języka czeskiego na niemiecki (np. Siatkowski 1993a) i ogólnie słowiańskie wpływy (przede wszystkim słowotwórcze) na język niemiecki i jego gwary (np. Siatkowski 1992, 2000b, 2015, 2017b), a także szczegółowo analizował pożyczki słowiańskie w gwarach niemieckich (por. np. Siatkowski 1994b, 1995, 1998a), ponadto część publikacji poświęcił slawizmom w utworach Horsta Bienka (np. Siatkowski 1996b) ze wspomnianą wyżej książką na ten temat na czele.

Niewątpliwie wszystkim wspomnianym wyżej zagadnieniom Jubilat poświęca dużo uwagi, jednak prawdziwą pasję badawczą Profesora Janusza Siatkowskiego zostawiłam na koniec. Otóż działem językoznawstwa, który od lat jest najbliższy jego sercu, jest geolingwistyka słowiańska i europejska. W tej dziedzinie nie ma sobie równych, pozostaje tu bezkonkurencyjnym ekspertem jako współautor

7 Praca ta oczywiście poświęcona jest także kontaktom łużycko-niemieckim. 
czterech atlasów językowych. Każdy z nich wiele mu zawdzięcza. Chronologicznie najwcześniejszy był wspomniany wyżej Atlas kaszubszczyzny i dialektów sąsiednich. Profesor Janusz Siatkowski jest współautorem tomu wstępnego atlasu, który ukazał się w roku 1964. Następnie pilotował kolejne tomy dzieła jako konsultant lub recenzent. Drugi z kolejności był międzynarodowy Общекарпатский диалектотогический атлас (Ogólnokarpacki atlas dialektologiczny). W roku 1981 ukazał się w Moskwie kwestionariusz do tego atlasu, którego Jubilat jest współautorem, a także członkiem Międzynarodowego Komitetu Redakcyjnego tegoż atlasu, jak również współredaktorem tomu trzeciego. Jest ponadto autorem aż 22 map atlasowych i komentarzy do nich oraz współautorem innych 12 map wraz z komentarzami (w różnych tomach dzieła). Profesor Janusz Siatkowski jest także autorem i współredaktorem $\mathrm{w}$ geolingwistycznym przedsięwzięciu na skalę ogólnoeuropejską, mianowicie współredagował tom piąty (wydany w roku 1997 w Rzymie) i siódmy (który ukazał się drukiem w roku 2007 również w Rzymie) Atlasu Linguarum Europae (ALE). Jest przy tym autorem dwóch map atlasowych (peigne 'grzebień, tomate 'pomidor') wraz z obszernymi komentarzami oraz współautorem jednej.

Atlasem, z którym Profesor Janusz Siatkowski związał się najmocniej, jest Общеславянский тингвистический атлас (Ogólnosłowiański atlas językowy, OLA). Jest to, jak wiadomo, ogólnosłowiańskie długofalowe przedsięwzięcie geolingwistyczne, ukazujące się w dwóch seriach, leksykalnej i fonetycznej ${ }^{8}$. Jubilat należy do Międzynarodowego Komitetu Redakcyjnego atlasu i jest współredaktorem 4 tomów leksykalnych (drugiego, czwartego, ósmego i dziewiątego) oraz jednego tomu fonetycznego (2b). Jest ponadto autorem i współautorem zapisów uogólniających do map leksykalnych atlasu ${ }^{9}$ oraz autorem 26 map i komentarzy do nich, a także współautorem 46 map wraz z komentarzami w różnych tomach atlasu.

Warto podkreślić, że jest to w sumie ogromny dorobek geolingwistyczny. Profesor Janusz Siatkowski ma niebywałe wprost doświadczenie w pracy nad atlasami. Swoją wiedzą w tym zakresie dzieli się w licznych publikacjach, nie tylko na temat samych atlasów i ich metod badawczych, ale też przedstawiając szczegółowe zagadnienia na kanwie map i materiałów atlasowych. Powstają $\mathrm{w}$ ten sposób wyczerpujące studia wyrazowo-pojęciowe w ujęciu historyczno-przestrzennym i porównawczym oraz prezentowane są przekrojowe zagadnienia ilustrowane innowacyjnymi, czytelnymi mapami, których próżno szukać w atlasach językowych. Do swoich wieloaspektowych badań (które mają za podstawę materiały i mapy atlasowe) Profesor Janusz Siatkowski wykorzystuje ponadto

8 Już w roku 1965 ukazał się kwestionariusz do atlasu, po nim zaś sukcesywnie kolejne tomy dzieła.

9 Warto pamiętać, że zapisy uogólnione są warunkiem powstania map leksykalnych, bowiem na podstawie samego tylko materiału gwarowego nie da się takich map skonstruować. 
wszelkie dostępne źródła i opracowania historyczne oraz gwarowe z wielu języków, a także historyczne i gwarowe słowniki. Z uwagi na to jego prace nie są omówieniami map atlasowych, ale stanowią dogłębne i wszechstronne analizy wybranych problemów. Takie podejście badawcze jest gwarancją wiarygodności przedstawianych rozwiązań.

Zagadnieniom związanym z Ogólnokarpackim atlasem dialektologicznym poświęcił Jubilat kilka publikacji. Część z nich odnosi się do samego atlasu (por. np. Siatkowski 1991c, 2016), część dotyczy szczegółowych problemów historycznojęzykowych i gwarowych, analizowanych w oparciu o materiały atlasowe (por. np. Siatkowski 1993b, 1999b). Podobnie przedstawiają się artykuły związane z Atlasem Linguarum Europae (ALE), niektóre dotyczą samego przedsięwzięcia (jak np. Siatkowski 1998b), a inne przekrojowych problemów leksyki europejskiej (np. Siatkowski 1989).

Niewątpliwie najwięcej publikacji Profesora Janusza Siatkowskiego wiąże się Ogólnosłowiańskim atlasem językowym (OLA). Prócz szeregu ogólnych artykułów o atlasie (np. Siatkowski 2002b, 2012) i jego teoretyczno-praktycznych problemach (por. np. Siatkowski 1998c, 2001-2002, Rembiszewska, Siatkowski 2003), Jubilat stworzył ogromną liczbę różnego rodzaju wnikliwych analiz w oparciu o materiały i mapy atlasowe, $\mathrm{z}$ wykorzystaniem wszelkich dostępnych źródeł i opracowań pozaatlasowych (por. wyżej). Jest zatem autorem jedynych w swoim rodzaju publikacji zarazem geolingwistycznych i dialektologicznych, jak również historycznojęzykowych, porównawczych i etymologicznych. Dotyczą one albo konkretnych pojęć z zakresu słowiańskich gwarowych nazw zawodów (np. Siatkowski 2003a, 2004, 2005a) i nazw części ciała (por. Siatkowski 2009, 2010, 2014), albo przekrojowych problemów, jak na przykład zapożyczeń i ogólnie kontaktów językowych (por. np. Siatkowski 2003b, 2005b, 2008, Rembiszewska, Siatkowski 2010). Część z tych prac została po ujednoliceniu wydana w osobnych książkach, które wymieniłam wyżej.

Przytoczone publikacje Profesora Janusza Siatkowskiego przekonują, że umie on łączyć wiele metod badawczych, co daje znakomite rezultaty. W swoich dociekaniach stosuje podejście geolingwistyczne, historyczno-porównawcze, dialektologiczne oraz wszelkie metody z zakresu teorii kontaktów językowych. Dzięki temu udaje mu się rozwiązać tak wiele problemów etymologicznych, historycznojęzykowych i dialektologicznych. W ten sposób Jubilat jest wzorem prawdziwego naukowca, i to takiego, który ze swojej pracy czerpie nie tylko satysfakcję, ale jest ona także źródłem jego radości i inspiracji.

Ożywiona twórczość naukowa i wymienione wcześniej funkcje administracyjne Profesora Janusza Siatkowskiego to tylko część jego bogatej działalności. Należał on i należy, jako ceniony ekspert, do licznych komitetów redakcyjnych i rad naukowych prestiżowych czasopism językoznawczych, a w niektórych pełnił 
rolę redaktora naczelnego lub przewodniczącego. W porządku chronologicznym są to następujące czasopisma i funkcje ${ }^{10}$ :

Studia z Filologii Polskiej i Słowiańskiej - sekretarz: t. VII (1967) - XV (1976); zastępca redaktora: XVI (1977) - XXII (1984); redaktor naczelny: XXIII (1985) - XXIV (1987); członek Komitetu Redakcyjnego XXV (1989) - XLV (2010); członek Rady Naukowej XLVI (2011) - XLVIII (2013);

Prace Filologiczne - członek Komitetu Redakcyjnego: XXV (1991) - L (2005), członek Rady Redakcyjnej: LI (2006) - LIV (2008), LVI (2009), LVIII (2010), LX (2011), LXII (2011), LXVI (2015).

Acta Baltico-Slavica - członek Komitetu Redakcyjnego: X (1976) - XVIII (1987). Slavia Occidentalis - członek Komitetu Redakcyjnego od 1979.

Przegląd Humanistyczny - członek Rady Redakcyjnej: XXXIX (1995) - LIV (2010).

Bohemistyka - członek Komitetu Redakcyjnego od 2001.

Rocznik Slawistyczny - przewodniczący Rady Redakcyjnej: LVII (2008) - LXIV (2015).

Nová čeština doma a ve světě - członek Rady Redakcyjnej od 2012.

Środowisko naukowe w Polsce i za granicą od dawna docenia jego wielki autorytet $\mathrm{w}$ dziedzinie slawistyki, toteż Profesor był i jest członkiem wielu polskich i zagranicznych gremiów naukowych oraz pełnił i pełni w nich szereg zaszczytnych funkcji z wyboru. Oto stosowna lista ${ }^{11}$ :

Międzynarodowy Komitet Slawistów - przewodniczący 1993-1998, obecnie członek honorowy;

Komitet Językoznawstwa PAN, 1967-2015 (wiceprzewodniczący 1975-1984);

Komitet Słowianoznawstwa PAN, od 1975 (przewodniczący 1991-1996, honorowy przewodniczący od 2001);

Towarzystwo Naukowe Warszawskie (członek korespondent od 1982, członek zwyczajny od 1985, przewodniczący Wydziału I Językoznawstwa i Literatury 1989-1991; obecnie członek honorowy;

Polskie Towarzystwo Językoznawcze, od 1954 (przewodniczący 1991-1993);

Białostockie Towarzystwo Naukowe;

Łomżyńskie Towarzystwo Naukowe im. Wagów;

Towarzystwo Filologów Bułgarystów - od 1986 członek honorowy;

Towarzystwo Jabłonowskich w Lipsku - od 1991;

Czeskie Towarzystwo Językoznawcze - od 1991 członek honorowy.

10 Informacje zaczerpnięte ze strony internetowej Instytutu Slawistyki PAN: : http://ispan. waw.pl/default/pl/uczeni-z-kregu-is-pan/1108-prof-dr-hab-janusz-siatkowski [dostęp 12.01.2019].

11 Dane głównie ze strony Instytutu Slawistyki PAN: http://ispan.waw.pl/default/pl/uczeni-zkregu-is-pan/1108-prof-dr-hab-janusz-siatkowski [dostęp 12.01.2019], por. też Popowska-Taborska 1999: 9-10; Dubisz 2014: 297. 
Do tego trzeba dodać, że Profesor Janusz Siatkowski był pierwszym przewodniczącym Rady Naukowej powstałego w roku 1973 Instytutu Języka Polskiego PAN. Funkcję tę pełnił w latach 1973-1980. Ponadto w latach 1991-1994 był członkiem Rady Naukowej Instytutu Łużyckiego w Budziszynie.

Za swoją wspaniałą pracę naukową, za działalność administracyjną i organizacyjną Profesor Janusz Siatkowski był wielokrotnie nagradzany w Polsce i za granicą. Nagrody te w kolejności chronologicznej przedstawiają się następująco ${ }^{12}$ : Złoty Krzyż Zasługi - 1973;

Medal „1300 lat Bułgarii” - 1982;

Order Cyryla i Metodego I klasy - 1986;

słowacki Order Podwójnego Białego Krzyża III klasy - 1998;

Krzyż Komandorski Orderu Odrodzenia Polski - 2000;

Medal Dobrovskiego, Czeska Akademia Nauk - 2001;

Medal Jubileuszowy 50-lecia PAN - 2002;

Medal Komisji Edukacji Narodowej - 2005.

Jednak najbardziej cenną nagrodą, najbardziej prestiżową, jest doktorat honoris causa Uniwersytetu Karola w Pradze, który został Profesorowi Januszowi Siatkowskiemu nadany w roku 1998 w uznaniu jego ogromnych zasług dla bohemistyki i slawistyki europejskiej.

Jak widać, dokonania Jubilata są olbrzymie na wielu polach. Bez żadnej przesady można stwierdzić, że jest prawdziwym tytanem pracy. Tylko dzięki temu zdołał osiągnąć tak wiele. Trzeba też podkreślić, że będąc światowej klasy uczonym, piastującym przez lata tak wiele ważnych funkcji, nie zatracił bezpośredniości, poczucia humoru i pogody ducha.

$\mathrm{Z}$ okazji pięknej dziewięćdziesiątej rocznicy urodzin niech mi będzie wolno najserdeczniej życzyć Drogiemu i Dostojnemu Jubilatowi długich lat w dobrym zdrowiu, wiele satysfakcji z publikacji i dalszych wspaniałych sukcesów naukowych. Życzę też gorąco, aby nadal zachował młodzieńczą werwę i zapał do wszystkiego, czego tylko się podejmuje, życzę również zawsze wspaniałego humoru i radości życia.

\section{Bibliografia}

Bałtowa Julija, Siatkowski Janusz, 1993, Koncepcja opisu słowotwórstwa w konfrontatywnej gramatyce bułgarsko-polskiej, [w:] Studia gramatyczne bułgarsko-polskie, t. V-VI: Konfrontacja językowa. Słowotwórstwo. Wybrane kategorie semantyczne, red. Violetta Koseska-Toszewa, Małgorzata Korytkowska, Warszawa, s. 11-27.

12 Dane o nagrodach dla Profesora Janusza Siatkowskiego pochodzą ze strony internetowej Instytutu Slawistyki PAN: http://ispan.waw.pl/default/pl/uczeni-z-kregu-is-pan/1108-prof-dr-habjanusz-siatkowski [dostęp 12.01.2019]. 
Dorobek naukowy Profesora Janusza Siatkowskiego, 2014, opr. Ignacy Doliński, Zdzisław Kłos, Dorota K. Rembiszewska, Warszawa.

Dubisz S., 2014, Profesor Janusz Siatkowski - polonista, bohemista, slawista, „Bohemistyka”, t. 3, s. 293-299.

Popowska-Taborska Hanna, 1999, O Profesorze Januszu Siatkowskim - oficjalnie (i mniej oficjalnie), „Prace Filologiczne”, t. XLIV, s. 9-12.

Rembiszewska Dorota K., Siatkowski Janusz, 2003, O możliwościach prezentowania zróżnicowania leksykalno-morfologicznego na mapach Atlasu ogólnosłowiańskiego, „Prace Filologiczne”, XLVIII, s. 473-478 + 4 mapy.

Rembiszewska Dorota K., Siatkowski Janusz, 2010, Wpływy obce w IX tomie OLA, [w:] Діалектологічні студії 9. Запозичення та інтерференція, Lwów, s. 19-35 + 4 тару.

Rembiszewska Dorota K., Siatkowski Janusz, 2015, Zróżnicowanie morfologiczne wyrazu *ormę 'ramię w językach i dialektach słowiańskich, „Jazykovedné štúdie”, 32: Prirodzený vývin jazyka a jazykové kontakty, Bratislava, s. 163-171.

Rembiszewska Dorota K., Siatkowski Janusz, 2016, Nawiązania czy pożyczki na pograniczu polsko-wschodniosłowiańskim?, „Rocznik Slawistyczny”, t. XLV, s. 67-87.

Rembiszewska Dorota K., Siatkowski Janusz, 2017, Nawiązania czy pożyczki na pograniczu polsko-wschodniosłowiańskim? Cz. II, „Rocznik Slawistyczny”, t. XLVI, s. 27-63 +2 mapki.

Siatkowska Ewa, Siatkowski Janusz, 1990, Słowackie nomina loci z przyrostkami -řa, -eň w słowniku Loosa i obecnie, [w:] Studia Linguistica Polono-Slovaca, t. III: Dynamika rozwoju słownictwa. Referaty z konferencji w Paszkówce 22-25 VI 1987, Wrocław, s. 71-77.

Siatkowski Janusz, 1958, Słownictwo Warmii i Mazur, I: Budownictwo i obróbka drewna, Wrocław, s. 137 i 64 mapy.

Siatkowski Janusz, 1959, Czechizmy w języku Jana z Koszyczek, International Journal of Slavic Linguistics and Poetics, I/II, s. 143-176.

Siatkowski Janusz, 1960, W sprawie nazw pomieszczeń dla zwierząt domowych na Warmii i Mazurach, „Język Polski”, r. XL, s. 237-240.

Siatkowski Janusz, 1962a, Dialekt czeski okolic Kudowy, cz. I: Fonetyka-Słowotwórstwo, Wrocław, s. 174.

Siatkowski Janusz, 1962b, Dialekt czeski okolic Kudowy, cz. II: Fleksja - Słownictwo Teksty, Wrocław, s. 204.

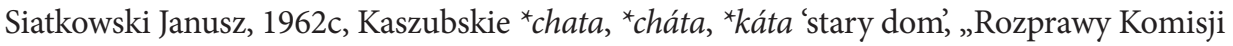
Językowej Łódzkiego Towarzystwa Naukowego”, t. VIII, s. 253-258.

Siatkowski Janusz, 1962d, Zróżnicowanie terytorialne Kaszub w zakresie występowania a ścieśnionego, „Slavia”, t. XXXI, s. 441-452.

Siatkowski Janusz, 1964, Warmińsko-mazurskie nazwy mieszkańca i mieszkanki wsi, „Prace Filologiczne”, t. XVIII/3, s. 253-260.

Siatkowski Janusz, 1965a, Bohemizmy fonetyczne w języku polskim, cz. I: 1. Grupy trat, tlat; $2 . h$ zamiast $g$; 3. Spółgłoski twarde przed $i, e$, Wrocław, s. 239.

Siatkowski Janusz, 1965b, Geografia kontynuantów á w kaszubszczyźnie na podstawie dawniejszych opracowań, „Studia z Filologii Polskiej i Słowiańskiej”, t. V, s. $407-413$. 
Siatkowski Janusz, 1965c, F. Hinze, Die deutschen Lehnwörter im Pomoranischen (Kaschubischen), „Rocznik Slawistyczny”, t. XXIV/1, s. 175-179.

Siatkowski Janusz, 1967a, Dwa Unglerowskie wydania Katechizmu (Reja), „Studia z Filologii Polskiej i Słowiańskiej”, t. VI, s. 87-109.

Siatkowski Janusz, 1967b, Wpływ poszczególnych dialektów niemieckich na język polski, „Studia z Filologii Polskiej i Słowiańskiej”, t. VII, s. 33-46.

Siatkowski Janusz, 1973, The Development of Polish Orthography, rozdział w pracy Z. Stiebera, A Historical Phonology of the Polish Language, Heidelberg, s. 147-151. Siatkowski Janusz, 1976, Badania nowych dialektów mieszanych i mowy miejskiej w Czechach, „Studia z Filologii Polskiej i Słowiańskiej”, t. XV, s. 269-283.

Siatkowski Janusz, 1978, Zakres i charakter wpływu języka czeskiego na polski, „Z polskich studiów slawistycznych", seria V: Językoznawstwo, Warszawa, s. 307-314.

Siatkowski Janusz, 1982, Altbulgarische Einflüsse auf das Altpolnische, Die slawischen Sprachen, t. II, Salzburg, s. 121-129.

Siatkowski Janusz, 1983a, Interferencje językowe na Warmii i Mazurach, „Studia z Filologii Polskiej i Słowiańskiej”, t. XXI, s. 103-115.

Siatkowski Janusz, 1983b, Polnische Interferenzen in deutschen Mundarten, Die slawischen Sprachen, IV (Salzburg), s. 119-131.

Siatkowski Janusz, 1984a, Czeskie wpływy fleksyjne w języku staropolskim, „Acta BalticoSlavica", t. XVI, s. 221-234.

Siatkowski Janusz, 1984b, За българско-полското съпоставително словообразуване, [w:] Втори колоквиум по български език, 20-24 август 1984 г., Научни материали, ч. II, Sofia, s. 98-113.

Siatkowski Janusz, 1985, O języku Historii rzymskich z 1543 roku, „Studia z Filologii Polskiej i Słowiańskiej”, t. XXIII, s. 87-98.

Siatkowski Janusz, 1986, Kryteria ustalania wpływu języków bliskospokrewnionych, [w:] Festschrift für Herbert Bräuer zum 65. Geburtstag am 14. April 1986, Köln-Wien, s. $551-563$.

Siatkowski Janusz, 1987a, Bułgarskie -ište i polskie -isko w nominach loci, [w:] Slawistyczne studia językoznawcze, Wrocław, s. 343-348.

Siatkowski Janusz, 1987b, Nomina loci в старобългарския език, [w:] КирилоМетодиевски студии кн. 4: Хиляда и сто години от смъртта на Методий, Sofia, s. $232-239$.

Siatkowski Janusz, 1988, За някои мними турски фразеологизми в българския език, [w:] В помощ на преподаването по български език на чуждестранни студенти, Sofia, s. 261-267.

Siatkowski Janusz, 1989, Europejskie paralele motywacyjne słownictwa słowiańskiego (na marginesie Atlasu języków Europy), [w:] Paralele w rozwoju słownictwa języków słowiańskich, Wrocław, s. 39-49.

Siatkowski Janusz, 1990a, Obecna sytuacja językowa w okolicy Kudowy, [w:] Tgolí chole Mêstró Gedenkenschrift für Reinhold Olesch, Köln-Wien, s. 117-123.

Siatkowski Janusz, 1990b, Rola języka czeskiego w rozwoju polszczyzny literackiej, Acta Universitatis Lodziensis, Folia Linguistica, 23: Polszczyzna średniowieczna i renesansowa, Łódź 1990, s. 137-144. 
Siatkowski Janusz, 1991a, Obce nazwy miast w języku czeskim i polskim, „Studia z Filologii Polskiej i Słowiańskiej", t. XXIX, s. 181-208.

Siatkowski Janusz, 1991b, Innerslawische und slawisch-nichtslawische sprachliche Interferenz im Bereich der Morphologie, „Studia z Filologii Polskiej i Słowiańskiej”, t. XXVII, s. 227-246.

Siatkowski Janusz, 1991c, Der Atlas der karpatischen Mundarten, Zeitschrift für Dialektologie und Linguistik, Jg. LVIII/3, Wiesbaden, s. 257-266 i 2 mapy.

Siatkowski Janusz, 1992, Słowiańskie wpływy słowotwórcze w języku i dialektach niemieckich, Z polskich studiów slawistycznych”, seria 8: Językoznawstwo, Warszawa, s. $235-240$.

Siatkowski Janusz, 1993a, O wpływach języka czeskiego na niemiecki (w związku z pracami P. Eisnera), „Poradnik Językowy”, z. 9-10, s. 552-555.

Siatkowski Janusz, 1993b, Ukr. dial. tokma 'umowa przy kupnie-sprzedaży', 'zaręczyny' na tle karpacko-bałkańskim, [w:] Munera linguistica L. Kuraszkiewicz dedicata, Wrocław, s. 307-311.

Siatkowski Janusz, 1994a, Polsko-czeskie kontakty językowe na terenie Polski, „Prace Filologiczne", t. XXXIX, s. 231-246.

Siatkowski Janusz, 1994b, Słowiańskie wyrażenia i zwroty jako źródła pożyczek w gwarach niemieckich, „Poradnik Językowy”, z. 1-2, s. 37-45.

Siatkowski Janusz, 1995, Morphologischer Einfluß der slawischen Sprachen auf die deutsche Sprache und deren Dialekte, Zeitschrift für Slawistik, 40, z. 3, s. 325-334.

Siatkowski Janusz, 1996a, Etymologia dial. burszówki, burtówki 'snopki w pierwszej warstwie poszycia dachu', „Język Polski”, r. LXXVI, 4-5, s. 281-284.

Siatkowski Janusz, 1996b, Slawismen in den Schlesienromanen Horst Bieneks, „Germanoslavica”, t. II (VIII), s. 47-56.

Siatkowski Janusz, 1997, Kasz. merlica - ps. ${ }^{*}$ mbrlica. [w:] Onomastyka i dialektologia, red. Hanna Popowska-Taborska, Jerzy Duma, Warszawa, s. 229-233.

Siatkowski Janusz, 1998a, Słowiańskie ${ }^{*}$ materica, ${ }^{*}$ matica jako pożyczki w gwarach niemieckich, [w:] Slawistyka 9. Tematy. Księga jubileuszowa w 70. rocznicę urodzin Profesora Leszka Moszyńskiego, Gdańsk, s. 220-224.

Siatkowski Janusz, 1998b, Atlas języków Europy (komunikat o obecnym stanie opracowań), [w:] Teoretyczne, badawcze i dydaktyczne założenia dialektologii, red. Sławomir Gala, Łódź, s. 79-80.

Siatkowski Janusz, 1998c, Odróżnianie warstwy morfologicznej od fonetycznej w Atlasie ogólnosłowiańskim, „Z polskich studiów slawistycznych”, seria IX, Językoznawstwo, Warszawa, s. 273-276.

Siatkowski Janusz, 1999a, Łużycki sufiks -awa w dialektach niemieckich Brandenburgii, [w:] Studia lingwistyczne ofiarowane Profesorowi Kazimierzowi Polańskiemu na 70-lecie jego urodzin, red. Wiesław Banyś, Leszek Bednarczuk, Stanisław Karolak, Katowice, s. 314-325.

Siatkowski Janusz, 1999b, O nemeckých vplyvoch v materiáloch Celokarpatského dialektologického atlasu, [w:] Nárečia a národný jazyk. Materiály z medzinárodnej vedeckej konferencie (Budmerice 24-26. septembra 1997), red. Adriana Ferenčíková, Bratislava, s. $115-123$. 
Siatkowski Janusz, 2000a, O leksykografii czeskiej, „Poradnik Językowy”, z. 1, s. 24-37. Siatkowski Janusz, 2000b, Wpływy słowiańskie na język i gwary niemieckie. (Stan badań, potrzeby badawcze), „Polonica”, t.t XX, s. 271-288.

Siatkowski Janusz, 2001, Znaczenia horyzontalne wyrażeń z leksemem dno w językach południowosłowiańskich, „Prace Filologiczne”, t. XLVI, s. 547-551.

Siatkowski Janusz, 2001-2002, O trudnościach w ustalaniu legend do map Atlasu ogólnosłowiańskiego, „Roczniki Humanistyczne”, t. XLIX-L. Językoznawstwo. Prace ofiarowane Profesorowi Zenonowi Leszczyńskiemu, Lublin, s. 373-378.

Siatkowski Janusz, 2002a, Nazwy pomidora w językach Europy, [w:] Studia dialektologiczne, t. II, red. Joanna Okoniowa, Bogusław Dunaj, Kraków, s. 201-204.

Siatkowski Janusz, 2002b, Ogólnosłowiański atlas językowy, „Warszawskie Zeszyty Ukrainoznawcze”, 13-14: Spotkania polsko-ukraińskie, red. Stefan Kozak, Warszawa, s. $367-371$.

Siatkowski Janusz, 2003a, Słowiańskie nazwy 'młynarza' w świetle materiałów gwarowych i historycznych, Славистички студии, т. 10, посветено на Проф. Зузана Тополињска, по повод седемдесетгодишнината, Скопје, s. 429-439.

Siatkowski Janusz, 2003b, Językowe wpływy tureckie w Atlasie ogólnosłowiańskim, „Studia Slavica Hungarica”, t. 48/4, Budapest, s. 379-392.

Siatkowski Janusz, 2004, Komentarz historyczno-etymologiczny do słowiańskich nazw 'murarza', „Slavica Slovaca”, t. 39, čis. 2, s. 137-142.

Siatkowski Janusz, 2005a, Słowiańskie gwarowe nazwy 'kucharki’ jako ilustracja konkurencji nazw rodzimych i obcych, „Prace Filologiczne”, t. L, s. 133-144.

Siatkowski Janusz, 2005b, Грчките лингвистички влијанија во Општословенскиот лингвистички атлас, [w:] Теории и методи, red. 3. Тополињска, Скопје, s. 229-243.

Siatkowski Janusz, 2008, Pożyczka turecka kapak 'powieka oka' w dialektach południowosłowiańskich, [w:] Reverendissimae Halinae Satkiewicz cum magna aestimatione, red. Grzegorz Dąbkowski, Warszawa, s. 325-329.

Siatkowski Janusz, 2009, Słowiańskie nazwy ‘płuc' i 'wątroby w świetle materiałów gwarowych i źródeł historycznych, „Rocznik Slawistyczny”, t. LVIII, s.135-162 + 2 mapy.

Siatkowski Janusz, 2010, Słowiańskie nazwy 'twarzy' i 'policzka' w świetle materiałów gwarowych i źródeł historycznych, „Rocznik Slawistyczny”, t. LIX, s. 91-125 + 2 mapy.

Siatkowski Janusz, 2011, Rosyjskie gwarowe морщки́ i морски́ 'zmarszczki', „Poradnik Językowy", z. 10, s. 5-9.

Siatkowski Janusz, 2012, Osiągnięcia Polski w zakresie badań nad Ogólnosłowiańskim atlasem językowym, [w:] Językoznawstwo w Polsce. Kierunki badań i perspektywy rozwoju. Materiały z sesji jubileuszowej Komitetu Językoznawstwa PAN, red. Maciej Grochowski, Warszawa, s. 83-89.

Siatkowski Janusz, 2014, Słowiańskie nazwy ‘stopy', 'podeszwy' oraz 'śladu stopy’ w świetle materiałów gwarowych i źródeł historycznych, "Acta Universitatis Wratislawiensis” 3578. Slavica Wratislaviensia, CLIX. Wyraz i zdanie w językach słowiańskich 8. Opis, konfrontacja, przekład, red. Iwona Łuczków, Michał Sarnowski, Wrocław, s. $427-449$.

Siatkowski Janusz, 2015, Od bicza do pejcza - o kontaktach językowych słowiańsko-niemieckich, „Poradnik Językowy”, z. 10, s. 32-39. 
Siatkowski Janusz, 2016, Karpacki atlas językowy, „Studia Łomżyńskie”, t. XXVI, s. 147160.

Siatkowski Janusz, 2017a, Co zostało z dialektu czeskiego w okolicy Kudowy?, [w:] Dynamika rozwoju gwar słowiańskich w XXI wieku,. red. Dorota K. Rembiszewska, Warszawa, s. 147-155.

Siatkowski Janusz, 2017b, Wpływy słowiańskie na język i gwary niemieckie, „Slavia Iaponica", 20, Tokio, s. 52-73.

Waniakowa Jadwiga, 1999, Nazwy pomidora w językach słowiańskich, [w:] Język - Teoria - Dydaktyka. Materiały z XXI Konferencji Młodych Językoznawców w Trzcinicy k. Jasła 27-29 maja 1998, red. Barbara Greszczuk, Rzeszów, s. 57-64. 